important effect upon the provisioning of those cities, which, by their railways, command the interion country.

Amer, Railroad Journal.

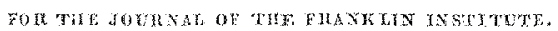

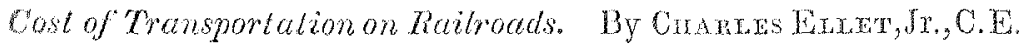

(Continuad from Vola IV, page 36\%.)

The importance of ascentang the exponse of transportation on whitroats, to a large potion of the population of this combtry, has led to many disetssions, and many inquines, with a riew to its dotemination. No general method has, however, yet been produed; by wheh it can be ascertand with any tolerable degrec of accuacy. The difliculy appears to have insen, in a great measure, from the fact, that theso exponses consise in a variety of elements, which increase and diminish in valuo by diferent laws, and at rates which Gyend on the combintions of these cloments in each particular case. It his, also, to some extent, grown out of the fatet, that during the jrogress of this system, every yoar ha produced some new work of moprovonent, which has supplied new data to calculators-and, unCortunately, data which have precedod the ofect of the two greatest causes of exponditure-the destruction consequent on ase, and natural decay. Withont reforing to another diliculy - the extravagant estimates of the friends of puricular projects, and, sometimes, the gross misrepresentations of the enemies of others-we see that the snbject is much too complicated to be unaveled without close study, and mature reflection. To make a general solution, we bave, obviously, to allow for diflerences of grade, differences of tonnage, differences botween the amounts of travel, and have dne regard to the length. and even the age of the improvement.

Now, to attempt to go through this whole subject, and prodnce and analyze the data on which are founded all my conclusions, would require much more labor, than Ihave a disposition, at this time, to ap. propriate to the question. What I now propose to do, is again to poin out the taw which governs railroad expenditures, and to fix, with greater accuracy, the values of the constant coeficients than ras practicable when I first offered the formula which are here repeated.

It is my intention to submit, in the frrst place, the law which gov. cus the expenditmes on a nev roud, and attempt to offer a reasonable explanation, and a just estimate, of the difference between the expenses ineident to a new road, and an old one. If my method be true, the reasons, and the values which I assign for this difference, must be obviously just. The general law must first satisfy the mind, and the rate of increase, in passing from a new to an old road, must likewise be rational and convincing. If, after this preparatory evidence, I bring forward a certain new road of great length, and show that the calculated cost corresponds well with the actual result, it will certainly be a strong confirmation of the general corlectness of the method. But still, for a pradent man proposing to risk his fortune, this alone ought not to be sutfieient. This particular example might be selected be- 
cause it was accidentally found to suit the object; he would have a right, therefore, to call on me to produce a short road, and stow that the results still correspond with my calculation. Mis intellect might not yet be fully satisfied; it would be fair for him to call for another example, in which the trade and travel were both unusually great, in order to be assured that the method is applicable to works of that character also; and, even after finding this result to be confrmatory of the method, extreme prudence would dictate an additional application to another road with very small trade.

All this appeang satisfactory, he cond not well retain a doubt, but, when men stake their fornos, and the comfort and indulgence of their families on the issue, they have a righ - they are bound-to exercise great circumspection. Such a party might, therefore, well call for an application of the method to an old roadmon to one that has arrived at maturity, at least,--in order to see whether his investment is likely to be permanently good.

If this doubt be also satisfed; if he finds that the application may be safely made to a road of this description; if, in addition, it is made to one of this sort vith a great trade-next, to one with a small tradethen to one with great travel and no tonnage; afterward to a long one, and, finally, to a short one; to some roads with light, and to others with heavy grades-and, if he find that it gives consistent re sults in all these varied applications - as a reasonable, and as an in telligerit man, he will be compelled to admit, that the method is in accordance with refe $x A w$, and that its results are the rrum.

It is such testimony that I propose to offer the reader, and I solicil his attention in order that he may judge furly of my consistency-for consistency is a test of truth.

The following propositions are what $I$ designate as laws:-

I. The cost of motive power, with engines of the same class, ispro. portional to the distance which the engines run. The cost per mile is nearly the seme on roads of all grades-the diference in expense on roads with different grades, consists not essentially in variations o the cost per mile run, but in variations of the number of miles which must be performed to do the same duty.

II. The repairs of the road, with equal trade, are proportional to its length; that is to say, ceteris paribus, it costs twice as much $t$ keep up a road 200 miles long, as it does to maintain one in the sam condition, of which the length is 100 miles; just as it costs twice a: much to run engines 200,000 miles, as it would to run the same clas of engines $100,000 \mathrm{miles}$.

III. The repairs of cars are proportional to the number of tons con veyed, and to the distance to which they are conveyed. It costs twic as much to repair cars which run two millions, as it does those whicl run one million of miles per annum. Again, it costs twice as muc: to repair cars which convey 20,000 tons a given distance, as it doe those which convey 10,000 tons the same distance. The same prin ciple applies equally to the conveyance of passongers; it applies als to accidents, incidentals, and contingencies-for these things increas with, and are proportional to, the increase of business. 
These may appear like self-evident truths, and they are, in fact, so glaring that they scarcely appear to have been looked on at all. The custom now is to regaro the expense of cars as proportional to the distance the engine runs. It is here made proportional to the distance the cars run. It is customary also to consider the repairs of the road as proportional to the distance traveled by the enginewhereas it is only proportional to the length of the road.

These are simple principles, and such as cannot well be doubted, or denied. It remains to state the values of the constants.

Repairs of Roads.

The repairs of a railroad, I have stated, must be divided into two classes-those which are dependent on, and those which are independent of, the amount of the tonage. Of the first division, the wear of iron depends entirely on the use, and the wear of the wood, but partially on the use. The rotting of timber, the cleaning ont of ditches, the repairs of culverts, embankments, \&e, are independent of the trade. But these items are not independent of time; the expenses of repairs increase but little until the wood in the sills, ties and rails, begins to decay, and require removal, when they usubly soon attain their maximum, and afterward diminish, until they reach a scond mini.m mum.

The following table exhibits the cost of repairs on six of the most successful roads in this comntry, which I have purposely selected from. different sections. The table embraces three roads of each of the two great classes-three wooden superstructures with plate rails, and three iron roads with $\mathrm{T}$ or $\mathrm{H}$ patterns.

By casting the eye down the columus, the progressive increase of expenses will be easily recognized. It must be borne in mind, however, that these numbers do not include the renewal of the iron-an item always charged to "extraordinary repairs," or "permanent improvements"- -as though iron rails were ever permanent, or theirdestruction extraordinary. Eventually, the cost of the new iron passes into capital stock, or finded debt.

TABLE showing the Tncrease of the Cost of Repairs of hailroads.

\begin{tabular}{|c|c|c|c|c|c|c|}
\hline \multirow[b]{2}{*}{ Year. } & \multicolumn{3}{|c|}{ Permanent Roads-T Rail. } & \multicolumn{3}{|c|}{ Wuoden hoads-Flat Bars } \\
\hline & $\begin{array}{l}\text { Boston } 8 \\
\text { Lowell. }\end{array}$ & $\begin{array}{l}\text { Boston \& } \\
\text { Proxid'ce. }\end{array}$ & $\begin{array}{l}\text { Boston \& } \\
\text { Worcester }\end{array}$ & $\begin{array}{l}\text { Utica do } \\
\text { Scherec'y }\end{array}$ & $\begin{array}{l}\text { Petersbarg } \\
\text { Road. }\end{array}$ & $\begin{array}{l}\text { S. Caro- } \\
\text { lina Road. }\end{array}$ \\
\hline $1836^{2}$ & & & & & 251 & $870^{*}$ \\
\hline 1837 & 546 & 285 & 206 & 354 & 664 & 880 \\
\hline 1838 & 611 & 411 & 281 & 830 & 542 & 1040 \\
\hline 1839 & 731 & 209 & 405 & 450 & 539 & 982 \\
\hline 1840 & 816 & 334 & 830 & 618 & 794 & 592 \\
\hline 1841 & 1200 & 597 & 784 & 837 & $85 \%$ & 547 \\
\hline $184 ?$ & 1350 & 514 & 903 & 935 & & 503 \\
\hline 1843 & & & & & & 375 \\
\hline
\end{tabular}

I may add the following notes of the cost of motive power per mile traveled by the engines, which are extracted from documents that were not in my possession when I first stated the cost per mile for passenger engines at 25 cents, and of freight engines at 30 cents.

* Finished in 1833 , when the expenses were very low. 
T.ABLE showing the Cost of Locomotive Pouter for 1842.

\begin{tabular}{|c|c|c|c|c|c|}
\hline Name of Road. & Miles run. & Expense. & $\begin{array}{c}\text { Cost per } \\
\text { mile. }\end{array}$ & Nong & 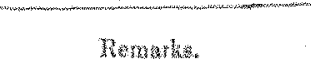 \\
\hline $\begin{array}{l}\text { Boston and Providence. } \\
\text { Boston and Providence. } \\
\text { Westero Road. } \\
\text { W. stern Road. } \\
\text { Urica and Schenectady. } \\
\text { Utica and Schenectady. } \\
\text { Rending Road. } \\
\text { Reading Road. }\end{array}$ & $\begin{array}{r}35,031 \\
77,774 \\
397,295 \\
357,295 \\
155,828 \\
155,828 \\
83,717 \\
198,0,55\end{array}$ & $\begin{array}{r}11,399 \\
23,352 \\
84,165 \\
115,000 \\
33,454 \\
52,268 \\
17,443 \\
49,800\end{array}$ & 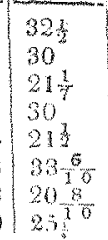 & 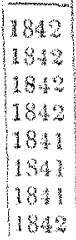 & 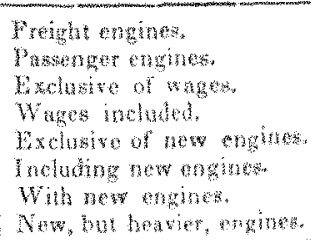 \\
\hline
\end{tabular}

This table entirely confirms the previous estmate (wol, 1, , p. 307.) Another table in my possession (derived from reports of 1 sit) gites for the average value of repairs of locomotives, 7 cents per niterua; my impression is, however, that this item is worth not less than 8 cents, and that future observation will maintain it, for cngines that axe not fresh from the factory, at about that avernge.

We may now pass to the method and the rule which I propose for computing the aggregate annual expenses of a rond. In the first mumberof this investigation, I proposed a formula which was published in this journal, for determining the ralue of these expenses-stating. however, that there was no line in the country wheh had yet exhbited results as favorable as those expressed by that formula. the present paper is intended to show these exponses tas they are: the same formula is used though the constants are modifed to wit the actual condition of the system.

\section{For new Rouls.}

The aggregate annul charges on new roud.5 are made up of the following items, viz: -

For every trile traveled by the engines, 21 cents; for every tonconreyed one mile, 9 mills; for every passenger conveyed one mile, 7 mills; and for every mile in length of the road, soo dolars, a fact which is expressed by the formula,

$$
\frac{24}{100} \mathrm{~N}+\frac{9}{1000} \mathrm{~T}+\frac{7}{1000} \mathrm{P}+300 \%
$$

Now, new engines consume as much, or nearly as much, frel and oil as those which have been used; and they require the same number of enginemen and firemen. The only reduction in the cost of their maintenance, consists in the item of repairs. The bill for repars for the first year or two, is only abont one-half its mean value: and as the average cost of repairs is about 7 cents per mile rum, the aggre. gate cost per mile run on a road which has passed its fouth year, should be $27 \frac{1}{2}$ cents, instead of 24 cents.

The limber in the superstructure is worth, on the average, from 1000 to 1500 dollars per mile, and lasts from 5 to 7 years. The decay of timber in roads of mature age, is, therefore, about $\$ 200$ per mileso that ordinary repairs on such roads will be about $\$ 500$ per mile.

The wear of cars after the road has been a few years in operation. is equivalent to about $4 \frac{1}{2}$ mills per ton per mile; and on a new road * I designate as new, roads less than fivo years olu. 
it is scarcely appreciable. The difference between the perceptible injury to the road and cars, on a new and old road, is about 5 mills per ton per mile. The rule then is, -

For old Rouds.

For every mile traveled by the engines, (passenger engines 25 and freight engines 30 cents, an average of $27 \%$ cents; for every ton conveyed one mile, 14 mills; for every passenger conveyed one mile, 7 mills; and for every mile of road, $\$ 500$.

If the principles and the values here offered be comect, they will stand the test of trial, and in order to make the test the strongest possible, 1 will add, in a subsequent paper, an estimate of the probable results on a road in active operation, and the subject of much spoculation at the present time, the correctuess of which ostimate can be verifed at the end of the year.

This rule, if applied to the business of a line in activity, will give only those expenses which are usually denominated sotinary expenses." In order to arrive at the lrue cost of maintenance we bave to add, of course, the extraordinary expenses, which we can like vise estimate with some, thongh not very greas, accuracy, by data now supplied by the improventents of the country.

Applicalion of the formale to active Wfortas.

I shall apply this mothod of compatation, in the first place, to a raitroad in Goorgia, 1475 miles long, with easy glades and litte bnsiness; Hext, to one in Massachuscts, 156 miles long, with grados of more than so fest to tho mile, on which the engines travel nearly four hundred thonsmo miles per annum, and where the trade and travel are both great; I will then apply it to a short road in the state of New York, which caries no tomage at all, but which derives its revenue ontirely from passengers, and which has moderate grades, and a moderate business; next, I will make the application to a road in Maryland 70 miles long, with grades of 84 feet, and which derives two-thirds of its revenue from tonuge. Finally, I will apply it to a road in Pennsylvania 56 miles long, with favorable grades and moderate business-ond again to the same road the next year, when extended 38 miles further, and having an increase of business.

The following lable gives the leught, grades and business of these roads; and, in the lwo last columus, are placed, side by side, the actual and caleulated expenses.

TABCE exhibiling the actual and computed cost of maineaining New Roads, calculated from the formula,

$$
\frac{24}{100} N+\frac{9}{1000} T+\frac{7}{1000} P+800 h
$$

\begin{tabular}{|c|c|c|c|c|c|c|c|c|}
\hline Name of lioual. & $\mid \begin{array}{l}\text { Levgrh } \\
\text { miles: }\end{array}$ & $\left\{\begin{array}{l}a^{\prime} d \mathrm{~d} \\
\text { in } \mathrm{dt}\end{array}\right.$ & $\begin{array}{l}\text { M. trav } \\
\text { ded by } \\
\text { jengines. }\end{array}$ & $\begin{array}{l}\text { Thro' } \\
\text { tonn'e. }\end{array}$ & $\begin{array}{l}\text { Thro' } \\
\text { travel. }\end{array}$ & Expenses. & Calculatd & Year. \\
\hline Georgia Roau, & $1 / 7 b_{2}$ & 37 & 152,873 & 10,000 & 12,000 & $\$ 100,819$ & 106,605 & 1842 \\
\hline Western Roal, & $156^{2}$ & 83 & 397,295 & 40,000 & 53,000 & 256,619 & 256,189 & 3842 \\
\hline Syracuse and Utien, & 53 & & 84,000 & & 70,769 & 62,325 & 02,315 & 1812 \\
\hline Baltim'e \& Susqueh'a & 70 & 84 & 128,349 & 23,000 & 16,500 & 75,224 & 74,379 & $184 \%$ \\
\hline Reading Road, & 56 & 19 & $83,7,7$ & 24,000 & 31,453 & 62,635 & 61,318 & 1841 \\
\hline Reading Road, & 94 & & 198,055 & 65,00 & 33,720 & 138,900 & 152,911 & 1842 \\
\hline
\end{tabular}


The roads named in this table are all those which have been completed less than four years, of which I have been able to procure the trade and travel, aggregate expenses, and distance run by the locomotive engines for the year 1842. In some of these I have been compelled to deduce the through tonnage from the receipts and prices - the reports giving only the aggregate tonnage;-in general the through travel is given with precision.

The agreement between the actual and calculated results in this table, is most remarkable, and exhibits a degree of miformity in the administration of the lines, which conld not have been anticipated. Indeed it is most probably becanse the roads are so new that the agreement is so perfect. When they begin to feel the effects of time and use, they will give way unequally, and exhibit much wider deviations from the rule. This fact is exemplified in the following table, which exhibits the resuits of experience on ten important railroads, selected from dif ferent sections of the country. The roads in this table vary in length from 14 milos to 136 miles; in grades from $10 \mathrm{ft}$, per mile, to $83 \mathrm{ft}$. per mile; in freight from nothing to 94,000 tons; in travel from 7,000 to 180,000 passengers; and in expenses from 30,000 to 225,000 dollars per annum.

TABLE exhibiting the actual and compated cost of maintaining roads which have been completed nore than four years, calculated by the formula,

$$
\frac{27.5}{100} \mathrm{~N}+\frac{14}{1000} \mathrm{~T}+\frac{7}{1000} \mathrm{P}+500 h
$$

\begin{tabular}{|c|c|c|c|c|c|c|c|c|}
\hline Name of Roads. & Year. & $\begin{array}{c}\mathrm{H}^{\prime} \mathrm{g} \text { gh } \\
\text { in } \\
\text { miles }\end{array}$ & $\begin{array}{l}\text { Code. } \\
\text { in } \\
\text { feet. }\end{array}$ & $\begin{array}{c}\text { Miles } \\
\text { run. }\end{array}$ & $\begin{array}{l}\text { Thr'gh } \\
\text { tonna'e }\end{array}$ & $\begin{array}{l}\text { Thr'gh } \\
\text { travel. }\end{array}$ & $\begin{array}{c}\text { Actual } \\
\text { expenses. }\end{array}$ & $\begin{array}{l}\text { Calculat } \\
\text { expenses. }\end{array}$ \\
\hline $\begin{array}{l}\text { Boston and Providence, } \\
\text { Daltim'e and Washing'n, } \\
\text { Petersburg Road, } \\
\text { Nashua and Lowell, } \\
\text { Haltimore and Ohio, } \\
\text { Portsmouth \& Roanoke, } \\
\text { Boston and Lowell, } \\
\text { Philadolp' \& Columb a } \\
\text { S. Carolina Road, } \\
\text { Boston and Worcester, }\end{array}$ & $\begin{array}{l}1842 \\
1841-2 \\
1842 \\
1841 \\
1842 \\
1842 \\
1842 \\
1842 \\
1842 \\
1842 \\
1841-2\end{array}$ & $\begin{array}{l}42 \\
30 \frac{1}{3} \\
61 \\
14 \\
82 \\
79 \\
26 \\
82 \\
136 \\
44 \frac{1}{2} \\
78\end{array}$ & $\begin{array}{l}38 \\
30 \\
10 \\
8 \% \\
10 \\
45 \\
35 \\
42\end{array}$ & $\begin{array}{r}120,000 \\
91,428 \\
131,160 \\
44,040 \\
299,617 \\
96,000 \\
143,607 \\
261,814 \\
260,324 \\
241,319 \\
152,764\end{array}$ & $\begin{array}{r}21,200 \\
27,360 \\
22,000 \\
28,663 \\
44,477 \\
5,975 \\
93,927 \\
27,000 \\
61,911\end{array}$ & $\begin{array}{r}117,129 \\
11,260 \\
16,000 \\
85,737 \\
34,380 \\
7,662 \\
179,819\end{array}$ & $\begin{array}{r}3101,596 \\
73,684 \\
96,398 \\
30,708 \\
220,135 \\
73,345 \\
131,012 \\
116,000 \\
225,743 \\
168,509 \\
154,436\end{array}$ & $\begin{array}{r}100,897 \\
76,166 \\
92,489 \\
33,131 \\
192,925 \\
76,703 \\
119,409 \\
112,979 \\
213,945 \\
176,815 \\
143,642\end{array}$ \\
\hline
\end{tabular}

[Nore-The miles mun on the Petersburg Road are assumed to be the same as in 1841; the tonnage is estimated from the tonnage of 1841 , with an allowance for the increased receipts. The results on the Baltimore and Ohio Road for 1841 are preferred, because those of 1842 are complicated by the extension of the line to Cumberland. The report of the Philadelphic and Columbia Road contains only the expenses of motive power and repairs; the freight and passengers are conveyed by other parties; we have, therefore, in the formula to make $\mathrm{P}=0$ and $\mathrm{T}=0$, for this case. The tonnage and travel on the South Carolina Road are deduced from the printed reports. The actual charges on some of the lines will be seen to differ from other published statements; this will be found to arise from the fact that 
these statements contain charges for interest, ferries, cars, and motive power on branch roads, which are rojected in this comparison.]

Here is presented a list of cloven roads, situated in different sections of the country, and offering cvery variety of length, grade and business that could be desired, in order to put the formula to the severest test. The greatest difference which is exhibited in the whole list between the actual anmal cost of mantenanee, and the estimated cost, is 12 per cent.; cortainly no closer agreement could be expected, since the netual expenditures fluctuate to that extent-and, perhaps, throngh wider limits-from year to year' the renovals of decayed timber, and varions contingeneies, being lound much more extensive some years than othors. In looking over the list I am able to account, in almost cvery instance, for these departures from the formula, by my personal knowledge of the situation of the line. It will probably be seen on some future occusion, that those roads which now exhibit expenses above the formula, will fall below it for other years-a rem mark which is applicable to the Boston and Lowell, Baltimore and Ohio, and South Carolina lioals.

It is no part of my object to flatter the expectations of railroad companies, but to exhibit to thom and the public the trath; to those companies whose works aro now new, and who seem to be making money, I would snggest the timoly formation of a contingent fund, to prepare them for a coningency which will as surely reach them as the next new yoar. It is had policy to divide the anmal expenses as if they were real profits; the money that is earned at the expense of the rails, cars, and machinery, should be hoarded to replace those things, and not distributed, as if they were to last forever. It can be shown that every company shonld annually store away, in times of prosperity, while their work is new, at least 6 cents for every mile travelled by their engines, 1 cent for every ton conveyed one mile, and 200 dollars for every mile of road, to replace decayed materials, and injured iron and machinery. If their profits will not permit that reservation, then the pradent man will avoid their stock; and the company should cut down their cxpenses to the limit assigned by the trade. Where these expenses do not consist of interest on debt, this retrenchment is almost always possible.

In the first of these tables the Reading Railroad appears to escape the application of the rule; the calculated expenses exceding the actual charges, as stated by tho company, some $\$ 14,000$, or about 10 per cent. There has probably been a division made between the current and contingent expenses on this line; indeed, on inspecting the published exhibit, I find that the whole sum set down for timber used in repairing 94 miles of road, including rails, sills, \&c, is just $\$ 2,431$. Now, I know personally, that twice that sum would not pay for the timber required for repairing the bridges alone; the bridge account last year must have amounted to more than $\$ 12,000$, and scems not to be included in the published statement. This sum being added to the published total, brings the year's expenses up to $\$ 151,000$, or within $1 \frac{1}{4}$ per ct. of the formula. Perhaps the company regard the loss of a bridge as so extraordinary an accurrence, that it can never take place again; but 
their report already points to another which is found to be sless permanent than the rest;" and timo will show that no part of railway superstructures will long renain permanent under the action of heavy engines and their trams. Besides there will be freshets, and tornadoes, and fres; and on a rond which has a great wany bridget constructed of perishable matrials, and which is traveled by 25 or $50 \mathrm{lom}$ comotives every day, or abmut 10,000 thins a year-whenghes nsing pine wood for hel-many accients must be expocted. One bridgo per anum is a small allowane for the average loss; and if the

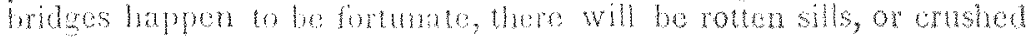
iron, enough to compensate for the difference.

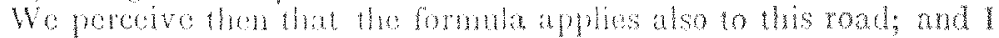
will now insert a table cxhbinger its application to all the rouds of which I have ben able wo ohim the amomat of trade, and ambex a column show ing the per centage of eror for ach not having the number of miles run by passenger and froight engines separately in every instance, I make low of the men vahe 27 sonts per mile rua.

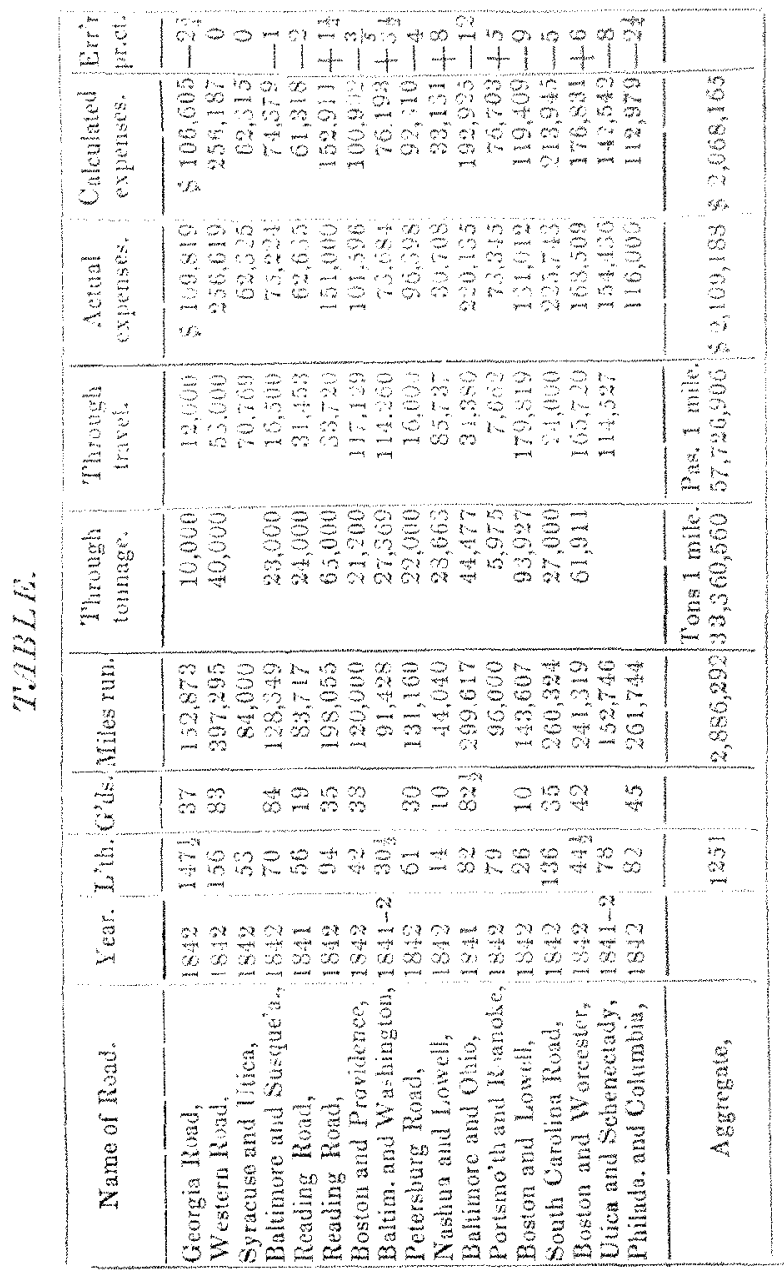


One word more in reference to this table. I offer here a list of 17 railroads, presenting almost every conceivable variety of length, grade, and character. It is not a selected table, but contains the results of one year's operations on every road, without exception, conm cerning which I have been able to obtain the necessary data-materials which have only been procured by dint of great exertion. It will be seen that the management upon these various lines is very nearly uniform, and that they are allobedient to the law. The greatest departure from the formula is 12 per cent.

Now, this list embraces roads which are siluated in every one of the sea-board States from Maine to Georgia; the aggregate length of line exhibited is 1251 miles; the engines traverse annually a space of $2,886,300$ miles, and they carry no less than $33,360,560$ tons, and $57,726,906$ passcngers ono mile. The aggregate ordinary expense of maintaining this lougth of line, and accommodating this amount of tonnage, is acmally $\$ 2,109,188$ amualy, and the calculated expense 58,068,165. The difference between the calculation and the fact is \$ 41,023 , or less thrn two por cent.

I conceive, therefore, that I heve authority sufficient for announcing this formula as expressing the law of railroad expenses-a law to which all the roads in the country are obedient. If stronger evidence of its correctness conld bo oflured, I know not in what it would consist. It is in vain 10 urge here that a certain road has peculiarly steep, or poculiarly light, wrades, which should cxompt it from the application of the rule. The formula which I announce, accounts for these differences. When the grades are easy, the engines make fewer miles, and the rule looks only to the miles.

There is yet another point of great importance connected with this subject, which ought not to be overlooked, viz., the "extraordinary expenses." It is the eustom among too many of the partics interested in the railroads of this country, to look upon the suggestion that iron may be worn out, as a thing so chimerical and visionary, as to be entirely unworthy of their sober thoughts. In the course of a few years they are surprised by the fact-the certainty - that money must be raised, and that their iron must be renewed. Instead of being warned by experience, and commencing immediately the work of retrenchment, and the provision of a surplus fund to meet the recurrence of the contingency, they look upon it as extraordinary in the extreme-a sheer accident, which cannot occur again, or which can be warded off by a heaver iron. Experience and common sense teach that heavier iron will be attended with heavier expense; but they have not yet tanght that the wear will be less. A heavier rail will longer resist a given trade; but will each dollar put into the heavy mil go farther? This, however, is a subject which must be reserved for a future number of the Journal.

So be Continued. 